\title{
İmalat Sanayiinde İthal Girdi Bağımlılığı: Trakya Bölgesi Örneği
}

\author{
Imported Dependence in Manufacturing Sector: A Case of Trakya Region
}

\author{
BurCu ŞENALP ${ }^{1}$ (D) , UMUt ERKSAN ŞENALP ${ }^{2}$ (D)
}

\section{Ö Z}

Bu çalışmanın amacı, Türk imalat sanayii sektörü için en önemli sorunlardan birisi olarak görülen ithal ara malı bağımlılığını Trakya bölgesi özelinde analiz etmektir. Çalışmamızda, Türkiye İstatistik Kurumu tarafından sağlanan firma seviyesindeki veriler kullanılarak 2003-2017 yılları arasında üretim sektöründe faaliyet gösteren firmaların ithal ara mal kullanım yoğunlukları hesaplanmıştır. Çalışmamızın literatüre katkısı, toplulaştırılmış veri kullanan diğer çalışmalardan farklı olarak, ithal bağımlılığını firma seviyesinde incelemiş olmasıdır. Gerçekleştirilen analizler sonucunda, bölgede faaliyet gösteren firmaların ithal bağımlılık oranın 2003 yılı ortalaması \%27,6 ile Türkiye ortalamasının üstündeyken, ylllar içerisinde gerileyerek 2015 yılında \%16 ile ülke ortalaması ile çok yakın bir seviyeye düştüğü tespit edilmiştir. Bu düşüşün temel nedeni olarak da bölgedeki ithalat talebinin önemli bir kısmını oluşturan "Tekstil ürünlerinin imalatı”, "Elektrikli teçhizat imalatı” ve "Giyim eşyalarının imalatı” gibi alt sektörlerde gözlenen ithal bağımlılığı oranındaki azalış gösterilmiştir.

Anahtar Kelimeler: İthal bağımlılığı, Mikro veriler, İmalat Sanayii.

Jel Siniflaması: D22, L6, F1.

\section{A B S T R A C T}

The level of import dependency is an important issue for Turkish manufacturing. The aim of our paper is to examine the degree of import dependency at the firm and sectoral levels for Trakya region. In order to calculate import dependency of manufacturing firms, we use firm-level data provided by Turkish Statistical Institute covering the period of 2003-2017. The contribution of our paper arises from the fact that we use firm-level data unlike the other papers in the related literature and it allows us to examine import dependency at the firm-level. We show that although import dependency in Trakya Region was 27,6\% in 2003, it decreased steadily over the 15 years and it levelled with the country average, $16 \%$, in 2015 . This decrease can be explained by the decrease in import dependency in some important sub-sectors in the region, such as "Manufacture of textiles", "Manufacture of electrical equipment" and "Manufacture of wearing apparel”.

Keywords: Import Dependency, Firm-level Data, Manufacturing Industry

Jel Classification: D22, L6, F1.

\section{DOI: $\underline{10.47934 / \text { tife.010.01.02 }}$}

*Bu çalışmada kullanılan "Yıllık İş Kayıt Çerçeveleri" verilerine erişim, TÜİK Edirne Bölge Müdürlüğü'nde bulunan Veri Araştırma Merkezi'nde gerçekleştirilmiştir. Bunu mümkün kılan Sayın Kenan Çelebi, Halil Emecen, Faruk Yılmaz Şişoğlu ve Settar Taha Işık’a teşekkür ederiz.

1. Dr. Öğr. Üyesi, Kırklareli Üniversitesi İktisadi ve İdari Bilimler Fakültesi, Kırklareli, Türkiye. ORCID: 0000-0003-1289-9888

2. Dr. Öğr. Üyesi, Trakya Üniversitesi Uygulamalı Bilimler Fakültesi, Edirne, Türkiye.

ORCID: 0000-0003-0261-3700

Sorumlu Yazar / CoRresponding Author

Umut Erksan Şenalp,

Trakya Üniversitesi Uygulamalı Bilimler Fakültesi, Edirne.

E-mail: uerksansenalp@trakya.edu.tr

$\begin{array}{ll}\text { BAŞVURU/SUBMITTED: } & 18.01 .2021 \\ \text { REVIZYON TALEBI / } & \\ \text { REVISION REQUESTED: } & 23.02 .2021 \\ \text { SON REVIZYON/ } & \\ \text { LAST REVISION: } & 03.03 .2021 \\ \text { KABUL / ACCEPTED: } & 14.03 .2021\end{array}$

Atıf / Citation: Şenalp, B., Şenalp, U. E. (2021). İmalat sanayiinde ithal girdi bağımlılığı: Trakya Bölgesi örneği. Trakya Üniversitesi İktisadi ve İdari Bilimler Fakültesi e-Dergi, 10(1), 11-24, https://doi.org/10.47934/tife.10.01.02 


\section{Giriş}

Dünya genelinde mal ve sermaye dolaşımını kısıtlayıcı eğilimlerdeki gerileme ve taşıma maliyetlerindeki düşüş, özellikle 1980 sonrası küresel ekonomide büyük bir değişime neden olmuş ve bu gelişmeler neticesinde uluslararası ticaret hacmi, tarihte görülmediği seviyelere ulaşmıştır. Bu gelişmelerin sonucu olarak, üretim süreçleri çok uluslulaşmış ve firmaların üretimde kullandıkları ara ve sermaye mallarının daha kalitelisine ya da daha ucuzuna uluslararası piyasalarda erişebilmesi mümkün olmuştur. Küreselleşme sonucu dünya ekonomisinde bahsedilen dönüşümler yaşanırken, Türkiye ekonomisi de bu dönüşümden etkilenmiş ve tarımdan sanayiye geçiş süreci başlamıştır. 1980 yılında dışa açılan Türkiye, 20 yıl içinde dünyanın en büyük 15 sanayi ülkesinden biri olmayı başarmış ve dış ticaret hacminin milli gelire oranı, 1990'ların başında yaklaşık \%24 iken, 2010'a yaklaşırken ikiye katlamış ve \%52'ye çıkmıştır. Ancak, sanayi üretimindeki bu ilerleme, üretim için gerekli olan ara malının ithalatında da yüksek oranlı artışlara neden olmuştur (Özenç ve Düşündere, 2017). Dış ticaretin arttığı bu dönemde, Türkiye'nin uluslararası rekabet açısından avantajlarının sınırlı olması, ülke ekonomisinin en önemli sorunlarından biri olan dış ticaret açığının oluşmasına yol açmıştır.

Bu süreçte dış açığı yaratan en önemli sebeplerden birisi, "ithalat bağımlılığı" olarak da adlandırılan, üretim değerindeki ithalat bileşeninin yüksek olması durumudur (Saygılı, Cihan, Yalçın ve Hamsici, 2010). Türkiye imalat sanayiinde ara malı ithalatı 2003 yılından itibaren hızlı bir yükselişe geçmiş ve 2010 yılında, 2003'e kıyasla, 1,5 kat ve 2016 yılına gelindiğinde ise 2 kat artış göstermiştir (Özcan-Tok ve Sevinç, 2019). Bu artış trendinin sonucu olarak, 2017 yılı itibari ile ara malı ithalatının tüm ithalat içindeki payı \%74'e ulaşmıştır. Diğer taraftan, Girdi Tedarik Stratejisi (GiTES) Eylem Planı, 2017-20 yıllarını kapsayan hedefleri kapsamında "Ithalata Olan Bağımlılı̆ın Azaltılması Öncelikli Dönüşüm Programı"nı kurgulamış ve yerli girdi üretiminin ve kullanımının teşvik edilmesi hedefini ortaya koymuştur (Ekonomi Bakanlığı, 2017).

Bir ülkede ithal bağımlılı̆ının artması, sektörlerdeki firmaların ithal girdi kullanımını arttırmaları veya ithal girdi bağımlılığı olan sektörlerin büyümesi yoluyla gerçekleşmektedir. İlgili literatür, Türkiye ekonomisinin dışa açılmasını takip eden süreçte bu iki durumun da gerçekleştiğini tespit etmiştir. Bunun yanı sıra, firmaları ithal ara malı kullanmaya iten nedenler, yurt içinde üretilen ara ve yatırım mallarının göreli olarak pahalı olması, kalitesinin ve üretim miktarının yetersizliği ya da bu malların ülkede hiç üretilmemesi olarak sıralanmıştır.

İthal ara malı bağımlılığı konusunda Türkiye üzerine yapılmış çalışmalar, imalat sektöründe ithal bağımlılığının sürekli bir artış içinde olduğunu göstermektedir. Bu çalışmanın amacı, 2003-2017 yılları arasında Trakya bölgesinde (Edirne, Kırklareli ve Tekirdağ) üretim sektöründe faaliyet gösteren firmaların ithal ara mal kullanım yoğunluklarını hesaplamak ve bu oranların 2003-2017 yılları arasındaki değişimini analiz etmek olacaktır. Bunun yanı sıra, bölgedeki ihracat kapasitesi yüksek olan sektörler üzerinden bir değerlendirme sunulacaktır. İlgili literatürde Türkiye imalat sektöründeki ithal bağımlılı̆ı üzerine yapılan çalışmaların neredeyse tamamı Türkiye İstatistik Kurumu'nun (TÜiK) girdi-çıktı tablolarından faydalanarak analiz gerçekleştirmişlerdir. Bu veriler sektörel ölçekte toplulaştırılmış olup, bir sektördeki tüm firmaların türdeş olduğu varsayımı ile analiz yapma imkânı sağlamakta ve firma düzeyinde ithal bağımlılığının nedenleri ya da sonuçları üzerine tahmin yapma olanağı vermemektedir. Çalışmamızın özgünlüğü, firma seviyesinde olan Yıllık Sanayi ve Hizmet İstatistikleri ile Dış Ticaret verilerini kullanarak, ithal ara malı bağımlılığını firma bazında incelemek olacaktır. Çalışmamı bu yönü ile ikinci bölümde incelediğimiz literatürdeki çalışmalardan farklılık göstermektedir. İthal girdi bağımlılığı ilk defa firma seviyesinde veri kullanılarak hesaplanacak ve bölgesel bir analiz ortaya konacaktır.

Bu çalışma, TÜik tarafından sağlanan ve firma ve ürün düzeyinde bilgi sağlayan Dış Ticaret verileri kullanılarak gerçekleştirilmiştir. Oluşturduğumuz panel veri seti, Trakya bölgesinde sanayi sektöründe faaliyet gösteren ithalatçı firmaları tespit etmemize olanak sağlamaktadır. Bu firmaların ithalat yapılarının 
yıllar içindeki değişimi, gerçekleştirdikleri toplam ithalat içinde ara malı, sermaye malı ve tüketim malının ne kadar yer tuttuğu üzerinden gerçekleştirilmiştir. Bunun yanı sıra kullandığımız veri seti, ithalata konu olan ürünlerin kaynağı olan ülkeler üzerinden de değerlendirmeler yapmamızı mümkün kılmaktadır.

Analizimiz sonucu elde edilen temel bulgular şu şekilde özetlenebilir: (a) Bölgenin en önemli ithal malı sağlayıcı ülkeleri Almanya ve Çin'dir, (b) Türkiye genelinden farklı olarak, bölgede faaliyet gösteren firmaların ithal bağımlılık oranları yıllar içerisinde gerilemiştir, (c) bölgedeki ithalat talebinin önemli bir kısmını oluşturan "Tekstil ürünlerinin imalatı", "Elektrikli teçhizat imalatı" ve "Giyim eşyalarının imalatı" alt sektörlerindeki üretim süreçlerinde kullanılan yerli girdi miktarının yıllar içerisinde arttığı tespit edilmiştir.

Çalışmamızın ikinci kısmında ilgili literatüre önemli katkı yapmış çalışmalar incelenecektir. Üçüncü kısımda kullanılan veri seti hakkında detaylı bilgi sağlanacak ve ithal bağımlılığı üzerine yaptığımız analizlerin bulguları paylaşılacaktır. Dördüncü kısım bulgularımızın özeti ve çalışmamızın sonucu olacaktır.

\section{Literatür}

\section{1 İthal Ara Malı Kullanımının Nedenleri ve Sonuçları}

Campa ve Goldberg (1997) 1970-1995 dönemini kapsayan ve ABD, Birleşik Krallık, Kanada ve Japonya üzerine yaptığı sektörel analizde, Japonya hariç diğer ülkelerin tamamında, hemen hemen tüm endüstrilerde ithal ara malı bağımlılı̆̆ının arttığını göstermiştir. Yıllar ilerledikçe, ara malı ithalatı dünya ticaretinde daha fazla pay sahibi olmaya başlamış ve yakın zamanda toplam ithalat içindeki payı yaklaşık olarak \%50’yi bulmuştur (Dutta ve Gosh, 2021). ilgili literatür, bu artışı açıklamaya yönelik olarak, "dış kaynak kullanımı", "küresel tedarik ağı" ve "çok uluslu şirket sayısındaki artış" olmak üzere üç ayrı hipotez üzerine odaklanmıştır. Örneğin, Feenstra ve Hanson (1996), artan ara mal ithalatını dış kaynak kullanımındaki artışa bağlamıştır. Buna göre, gelişmiş ülkelerde faaliyet gösteren firmalar, emek yoğun olan üretim süreçlerini, iş gücünün ucuz olduğu ülkelere kaydırmak için o ülkelere Doğrudan Yabancı Yatırım gerçekleştirirler. Sonuç olarak bu durum, üretim sürecinde ara mal ithalatı gerekliliği yaratmış olacaktır. Diğer yandan, çok uluslu şirket sayısındaki artışın ara mal ithalatındaki artışa neden olduğunu ortaya koyan çalışmalar, çok uluslu firmalar ve bu firmaların farklı ülkelerde bulunan kendi birimleri arasında gerçekleşen yoğun ticaretin, ara malı ithalatı üzerine etkisine odaklanmışlardır. Örneğin, Andersson ve Fredriksson (2000), 1974-1990 yıllarını kapsayan ve İsveç'te faaliyet gösteren sanayii firmalarından oluşan panel veri ile gerçekleştirdiği analizde, çok uluslu firmaların uluslararası üretim süreçlerinin, ara mal ithalatını pozitif yönde etkilediğini göstermişlerdir. Son olarak, ara mal ithalatındaki artışa yönelik bir diğer açıklama, küresel tedarik ağındaki gelişmelerdir. Buna göre firmalar, küreselleşmenin avantajlarından faydalanarak, fiyat, kalite ve tedarik kolaylığı gibi kriterler üzerinden, kendileri için en uygun şartları sağlayan ülkeden ara malı ithal etmektedirler (Kleinert, 2004).

Ithal girdi kullanımının doğrudan etkilerini inceleyen literatüre bakacak olursak, iki temel bakış açısı dikkat çekmektedir. Bunlardan birincisi, üretim sürecinde ithal ara malı kullanımının, üretimi dış şoklara karşı kırılgan bir hale getireceğinden ve bununla birlikte dış ticaret açığına neden olacağından bahsetmektedir. Örneğin, Ueda (1983), 1966-1980 döneminde ara mal ithalatının Japonya'nın dış ticaret dengesi üzerinde önemli etkisi olduğunu göstermiştir. Benzer şekilde, Lopez ve Rodrik (1990) geliştirdikleri teorik model aracılığı ile, gelişmekte olan ülkeler gibi ara mal ithalatı yoğun olan ülkelerin dış ticaret dengesini sağlamak amacıyla ithal ara malını kısıtlayıcı vergi uygulamasına gitmesinin arz şoku yaratıcı bir etkiye sahip olabileceğini ve bunun dış ticaret dengesini daha da kötü duruma getirebileceğini göstermişlerdir. Dutta ve Gosh (2021), ithal ara malı fiyatındaki artışın nitelikli iş gücü ile niteliksiz iş gücü arasındaki ücret eşitsizliğine etkisini incelemişlerdir. Üç sektörlü bir genel denge modeli analizi sonucunda, ithal ara malına uygulanan tarifelerdeki artışın bu girdilerin fiyatını arttıracağını, bunun yaratacağı etkinin de niteliksiz iş gücü ücretinde artışa, nitelikli iş gücü ücretinde ise düşüşe yol açacağını, dolayısıyla ücret eşitsizliğinde azalma gerçekleşeceğini göstermişlerdir. Buna ek olarak, Dutta ve Gosh (2021), ithal ara 
malına uygulanan tarifelerin düşürülmesinin, yani serbest ticaret durumunun, ücret eşitsizliğini arttırıcı bir etkiye sahip olduğu tespit etmiştir.

Öte yandan, ithal girdi kullanımının o kadar da olumsuz bir durum olmadığını ortaya koyan çalışmalar da vardır. Buna göre, ithalatçı firma, yurtdışı piyasalardan temin ettiği ara malı ya da yatırım malı yoluyla daha ileri teknoloji ile üretilmiş dolayısı ile daha kaliteli ürünlere erişebilir. Böylece, ithalata konu olan ürünün kaynağı olan ülkede kullanılan bu teknoloji, ithal ara ve yatırım malları üzerinden ithalatçı firmaya aktarılabilir. Bu şekilde gerçekleşen teknoloji transferi, ithalatçı firma ve endüstrilerde daha verimli üretim gerçekleştirilmesini sağlayabilir. Buna ek olarak, yerli üreticinin uluslararası piyasadan daha ucuz ve daha kaliteli ara malı ithal etmesi sonucu firmaların maliyetlerinin düşeceği ve verimliliğin artacağı öngörülmektedir (Özcan-Tok ve Sevinç, 2019).

Amiti ve Konings (2007), 1991-2001 yılları arasında Endonezya'da faaliyet gösteren imalat sanayiindeki firmaların verimliliği ile gümrük tarifelerinin azaltılması arasındaki ilişkiyi incelemiş ve ara mala uygulanan gümrük tarifesinde \%10'luk bir azalmanın o ara malı ithal eden firmanın verimliliğinde \%12'lik bir artışa sebep olduğunu tespit etmiştir. Almeida ve Fernandes (2008), gelişmekte olan 43 ülke üzerine 2002-2005 yıllarını kapsayan çalışmasında, Dünya Bankası'nın seçilmiş firmalardan anket yoluyla derlemiş olduğu Yatırım Ortamı Anketini kullandığı çalışmasında, ithalatın yerli firmalar için teknoloji transferinin önemli bir yolu olduğunu göstermişlerdir. Kasahara ve Rodrigue (2008), firma düzeyinde veriyle yaptıkları analizde, Şili imalat sanayiinde üretim yapan firmaları yerli ara malı ve ithal ara malı kullanan firmalar olmak üzere gruplandırmış ve bunun verimlilik ile ilişkisini incelemişlerdir. Elde ettikleri bulgular, üretici firmanın yerli ara malı kullanımından ithal ara malı kullanımına geçişini takiben \%2,6 verimlilik artışı yaşadıklarını göstermektedir.

Veeramani (2008) Birleşmiş Milletler tarafından sağlanan Comtrade veri setini kullanarak oluşturduğu ve yüzden fazla ülkeyi kapsayan panel veriyi kullanarak gerçekleştirdiği analiz sonucunda, ithal ara malının bilgi yayılımı sağlaması sonucu ekonomik büyüme yaratıcı etkisini tespit etmiştir. Goldberg, Khandelwal, Pavcnik ve Topalova (2010), Hindistan'ın 1991 yılı sonrasındaki dışa açılma politikası çerçevesinde, ithal ara malı kullanımının yeni ürün geliştirme ve üretme sürecine etkisini incelemişlerdir. Firma seviyesinde yapılan analiz sonuçları, yeni ithal ara mala ulaşan firmaların üretiminde bir artış olduğunu göstermektedir. Yazarlar, bu bulguyu ekonominin geneli üzerinden değerlendirerek ithal ara malı kullanımının milli geliri arttırıc etkisini vurgulamışlardır. Halpern, Koren ve Szeidl (2015), 1993-2002 yılları arasında Macaristan üretim sektöründe faaliyet gösteren firmalar üzerinden verimlilik ve ithalat ilişkisini incelemiş ve bu yıllar arasında yaşanan verimlilik artışının \%25'inin ithal ara malı sayesinde olduğunu hesaplamışlardır. Bununla birlikte, gümrük vergilerine uygulanan indirimlerin verimliliği arttırıcı etkisinin, ithalatçı firma sayısının fazla olduğu yıllarda daha yüksek olduğu tespit edilmiştir.

Feng, Li ve Swenson (2016), 2002-2006 yıllarını kapsayan ve Çin firmalarının dış ticaret verilerinin kullanıldığı çalışmada, ithal ara malı kullanımının firmaların ihracat miktarını arttırdığını, bu etkinin ihracata sonradan başlayan firmalar için daha büyük olduğunu göstermişlerdir. Buna ek olarak, gelişmiş ülkelerden ara mal ithal eden firmaların, tekrardan gelişmiş ülkelere ihracat yapma ihtimallerinin arttığını tespit etmişlerdir. Roy (2020), Dünya Bankası'nın derlediği Verimlilik ve Yatırım İklimi Anketi verilerini kullanarak hazırladığı ve gelişmiş ve gelişmekte olan yaklaşık 40.000 firmayı kapsayan veri seti ile gerçekleştirdikleri analiz sonucunda, ithal ara mal kullanan firmaların ihracat hacimlerinin daha yüksek olduğunu göstermiştir.

\subsection{Türkiye İmalat Sanayii Üzerine Yapılan Çalışmalar}

Türkiye üzerine yapılan çalışmalara baktığımızda, Yükseler ve Türkan (2008) TÜiK'in yayımladığı 1998 ve 2002 yıllarının girdi-çıktı tablolarından faydalanarak, 1998 yılında imalat sanayii genelinde ithal girdi/üretim oranını yüzde 14,8 olarak tespit etmişlerdir. Özcan-Tok ve Sevinç (2019), 2002 ve 2012 
yıllarına ait girdi-çıktı tabloları kullanılarak hesapladığı ithalat gereği katsayısı imalat sektörü için 2002 yılında yüzde 16,1 iken 2012 yılında yüzde 19,3'e çıkmıştır.

Aydın, Saygılı, Saygılı ve Yılmaz (2010), 1980-2000 yılları arasında gelişmiş ülkelerin ara malı ihracatçısı, gelişmekte olan ülkelerin ise net ithalatçı olduğunu ve bu ülkeler arasında en yüksek ara malı ithal oranına Türkiye'nin, en düşük orana ise Çin'in sahip olduğu tespit etmişlerdir. Ayrıca, Türkiye'de en yüksek ithal ara mal kullanımının ulaştırma araçları ve makine teçhizat sektörlerinde gerçekleştiğini göstermişlerdir. Bu bulgulardan farklılaşır bir şekilde Akat (2019), OECD tarafından hazırlanan Katma Değer Dış Ticareti (Trade in Value Added) verilerine atıfta bulunarak, Türkiye'de 2005'te \%15,4 olarak hesaplanan ihracatın ithalata bağımlılığının arttığını ve 2016'da \%16,4'e ulaştığını tespit etmiştir. Akat, buna ek olarak, kimi gelişmekte olan ülkelerle kıyaslandığında en düşük ithal aramalı kullanım oranlarının Türk imalat sanayiinde olduğunu belirtmiştir.

Saygılı ve ark. (2010), tekstil, giyim ve kimya/ilaç gibi ihracat oranı ve ithal girdi kullanımı yüksek sektörlerden toplam 145 sanayi firması ile yapılan yüz yüze görüşmeler neticesinde, firmaların yaklaşık \%60'ının ara mal ithalat nedenini ilgili ara malının yurt içi üretimin olmaması veya yurt içi üretim miktarının yetersizliği olarak belirtmişlerdir. İthalatçı firmalar bir diğer sebep olarak da Çin ve Hindistan gibi pazarların ucuzluğunu göstermişlerdir. Bununla birlikte, 2002-2007 döneminde sanayi mallarının üretiminde kullanılan ithal girdilerin payında önemli artış olduğunu raporlamışlardır. Özenç ve Düşündere (2017), 1980'lerden 2000'li yıllara gelinirken Türkiye'de ithal bağımlılığı ile birlikte dış ticaret açığının da arttığını vurgulamış, üretim sürecinde yaratılan katma değerin de arttığını tespit etmişlerdir. Bununla birlikte, ithal bağımlılığının görece daha fazla olduğu yüksek ve orta düzey teknoloji kullanan sektörlerde katma değer artışının sınırlı kaldığı raporlanmıştır. Bu nedenlerle Özenç ve Düşündere (2017), ithal ara mal kullanımındaki artışın beraberinde katma değer artışını getirmediğini ortaya koymuştur.

Eşiyok (2008), Türkan (2006), Ersungur ve Kızıltan (2007), Demir ve Kula (2008) gibi çalışmalar da TÜik'in girdi-çıktı tablolarını kullanarak gerçekleştirdikleri analizler sonucunda, imalat sanayi genelinde ithal bağımlılığının yıllar içinde artış eğiliminde olduğunu tespit etmişlerdir. Bu bulgular ışığında, şu aşamaya kadar derlediğimiz çalışmaların çoğu, Türkiye'de ithal bağımlılık oranlarının benzer şekilde devam etmesi durumunda cari açığın artacağından ve ülke ekonomisinin dışa bağımlı kalma tehlikesi ile karşı karşıya olacağından bahsetmektedir.

Alkın (2020), 2000-2014 dönemine ait girdi-çıktı tablolarını kullanarak gerçekleştirdikleri çalışmada, incelenen dönemde üretim sektöründe ithal bağımlılığında \%6'lık bir gerileme tespit etmişlerdir. Diğer yandan, Dineri ve Işık (2021), 2007-2018 yıllarını kapsayan ve aylık dış ticaret verileri kullanılarak yapılan çalışmalarında, Türkiye'de imalat sanayiinde ara malı bağımlılığını en çok etkileyen etmen döviz kurları olarak tespit edilmiştir.

İlgili literatürün incelemesi göstermektedir ki Türkiye imalat sektöründeki ithal bağımlılığı üzerine yapılan çalışmaların neredeyse tamamı TÜiK'in girdi-çıktı tablolarından faydalanarak analizlerini gerçekleştirmişlerdir. Girdi-çıktı tablolarından elde edilen veriler, sektörel ölçekte toplulaştırılmış olup bir sektördeki tüm firmaların türdeş olduğu varsayımı ile analiz yapma imkânı sağlamaktadır. Bu nedenle, adı geçen çalışmaların bulguları endüstri özelinde olup, firma düzeyinde ithal bağımlılığının nedenleri ve sonuçları üzerine tahmin yapma olanağı vermemektedir. Bu çalışmada, Türkiye imalat sanayi üzerine yapılan diğer incelemelerden farklı olarak, sadece bir sektör hakkında değil sektörleri oluşturan firmalar üzerine detaylı analizler ortaya konacaktır.

\section{Veri Seti ve Analiz}

Bu çalışma, TÜik tarafından sağlanan Dış Ticaret ve Yıllık Sanayi ve Hizmet İstatistikleri (YSHi) verileri kullanılarak gerçekleştirilmiştir. Dış Ticaret veri seti, 2005-2018 yıllarını kapsayan ve Ticaret Bakanlığı'nın Gümrük Beyannameleri üzerinden derlenen çok kapsamlı bir veri kaynağıdır. Bu veri setinin 
sağladığı bilgiler: İthalat ve ihracat faaliyeti gerçekleştiren firmaların bulunduğu il, ithalat ve ihracat tutarı (yabancı para ve TL üzerinden) ve miktarı (kg/adet gibi), ithal ürünün temin edildiği ülke, ihraç ürünün satıldığı ülke, ürünün 12 haneli Gümrük Tarifesi İstatistik Pozisyonu ve son olarak firmanın faaliyet gösterdiği endüstri bilgisi şeklinde sıralanabilir. Bunlara ek olarak, Dış Ticaret veri seti ithal ya da ihraç edilen her bir ürün için, Standart Uluslararası Ticaret Sınıflamasına Dayalı Geniş Ekonomik Gruplara Göre Sınıflama (BEC) sistemine göre düzenlenen bir kod sağlamaktadır. Bu kod, uluslararası ürün sınıflandırmalarında kullanılmakta olup her bir ithal ya da ihraç ürününü sermaye malı, ara malı ya da tüketim malı olarak sınıflandırmayı mümkün kılmaktadır. ${ }^{1}$ Dış Ticaret verilerinde, her bir firmaya vergi kimlik numaraları kullanılarak bir kimlik numarası (ID) atanmış olduğu için, firmaların yıllar içindeki dış ticaret faaliyetleri takip edilebilmektedir.

Bu çalışmada kullandığımız diğer veri kaynağı ise Yıllık Sanayi ve Hizmet İstatistikleri'dir (YSHI). Bu veriler, 2003-2015 yıllarını kapsamakta ve üretim ile hizmet sektörlerinde faaliyet gösteren ve 20'den fazla çalışanı olan firmalara ait endüstri, ciro, çalışan sayısı, sahiplik yapısı, firma yaşı ve maliyetler gibi bilgileri sağlamaktadır. Dış Ticaret veri setinde firmalara verilen kimlik numaraları, YSHi ile uyumlu olduğundan bu iki veri seti birleştirilerek tek bir veri seti elde edilebilmektedir. Biz de bu iki veri setinin kesişim yılları olan 2003-2015 dönemini dikkate alarak gerçekleştirdiğimiz birleştirme işlemi sonucunda 1734 firma ve 10524 gözlemden oluşan bir panel veri seti elde etmiş olduk.

Tablo 1: Yıllara Göre Dış Ticaret Yapan Firma Sayıları

\begin{tabular}{|l|c|c|c|c|}
\hline & $\begin{array}{l}\text { Sadece } \\
\text { ihracat yapan } \\
\text { firma sayısı ve } \\
\text { yüzdesi }\end{array}$ & $\begin{array}{l}\text { Sadece ithalat } \\
\text { yapan firma } \\
\text { sayısı ve } \\
\text { yüzdesi }\end{array}$ & $\begin{array}{l}\text { Hem ithalat hem } \\
\text { ihracat yapan } \\
\text { firma sayısı ve } \\
\text { yüzdesi }\end{array}$ & $\begin{array}{l}\text { Dış ticaret } \\
\text { yapmayan } \\
\text { firma sayısı ve } \\
\text { yüzdesi }\end{array}$ \\
\hline 2003 & $75(\% 14)$ & $64(\% 12)$ & $105(\% 19)$ & $295(\% 55)$ \\
\hline 2004 & $112(\% 13)$ & $199(\% 23)$ & $132(\% 15)$ & $418(\% 49)$ \\
\hline 2005 & $144(\% 16)$ & $77(\% 9)$ & $155(\% 17)$ & $524(\% 58)$ \\
\hline 2006 & $172(\% 17)$ & $75(\% 8)$ & $155(\% 16)$ & $591(\% 60)$ \\
\hline 2007 & $190(\% 19)$ & $92(\% 9)$ & $162(\% 16)$ & $557(\% 56)$ \\
\hline 2008 & $180(\% 18)$ & $83(\% 8)$ & $175(\% 18)$ & $550(\% 56)$ \\
\hline 2009 & $196(\% 21)$ & $74(\% 8)$ & $175(\% 19)$ & $500(\% 53)$ \\
\hline 2010 & $182(\% 16)$ & $80(\% 7)$ & $179(\% 16)$ & $669(\% 60)$ \\
\hline 2011 & $168(\% 13)$ & $89(\% 7)$ & $195(\% 16)$ & $801(\% 64)$ \\
\hline 2012 & $186(\% 13)$ & $84(\% 6)$ & $198(\% 14)$ & $951(\% 67)$ \\
\hline 2013 & $189(\% 13)$ & $70(\% 5)$ & $209(\% 14)$ & $1026(\% 69)$ \\
\hline 2014 & $139(\% 11)$ & $70(\% 5)$ & $192(\% 15)$ & $908(\% 69)$ \\
\hline 2015 & $132(\% 11)$ & $58(\% 5)$ & $176(\% 15)$ & $823(\% 69)$ \\
\hline
\end{tabular}

Kaynak: TÜiK Dış Ticaret mikro verileri, yazarların kendi hesaplamaları

\subsection{Bölge İthalatının Analizi}

Tablo 1, Trakya bölgesinde üretim yapan firmaları dış ticaret faaliyet durumlarına göre raporlamaktadır. Yıllara göre, sadece ihracat yapan, sadece ithalat yapan, hem ithalat hem ithalat yapan ve dış ticaret faaliyetinde bulunmayan olmak üzere gruplara ayrılmışlardır. Buna göre, 2003 yılında gözlemlenen firmaların yaklaşık \%55'i herhangi bir dış ticaret faaliyetinde bulunmazken, yaklaşık \%14'ü sadece ihracat,

${ }^{1}$ Bu sınıflandırmaya göre 111, 121, 21, 22, 31, 322, 42 ve 53 kodlu ürünler ara mal olarak sınıflandırılmıştır. 
\%12'si yalnızca ithalat ve \%19'unun hem ithalat hem ithalat yaptığı tespit edilmiştir. 2015 yılına gelindiğinde bu oranlar sırasıyla \%69, \%11, \%5, \%16 olmuştur. Yıllar içinde sadece ihracat yapan firma oransal olarak çok değişmezken, sadece ithalat yapan firmalarda oransal olarak düşüş yaşanmıştır. 2015 yılı itibari ile hem ithalat hem de ihracat yapan firmalar, bölgedeki firmaların yaklaşık \%15'i civarında iken dış ticaret faaliyetlerinde bulunmayan firmalar yaklaşık olarak \%69'ık bir paya sahiptir.

Şekil 1 Trakya bölgesinde gerçekleşen ithalatın çok yüksek kısmının Tekirdağ'da faaliyet gösteren firmalar tarafından yapıldığını göstermektedir. Örneğin, 2003 yılında toplam ithalatın \%86,2'si Tekirdağ'da bulunan firmalar tarafından gerçekleştirilirken, bu oran Kırklareli'ndeki firmalar için \%9,6 bulunmuş ve Edirne'nin payı sadece \%4,2 olmuştur. 2008-12 yıllarında gerçekleşen artış hariç, Edirne' de üretim yapan firmaların ithal malı talebinin bölge içindeki payının oldukça düşük kaldığı görülmektedir.

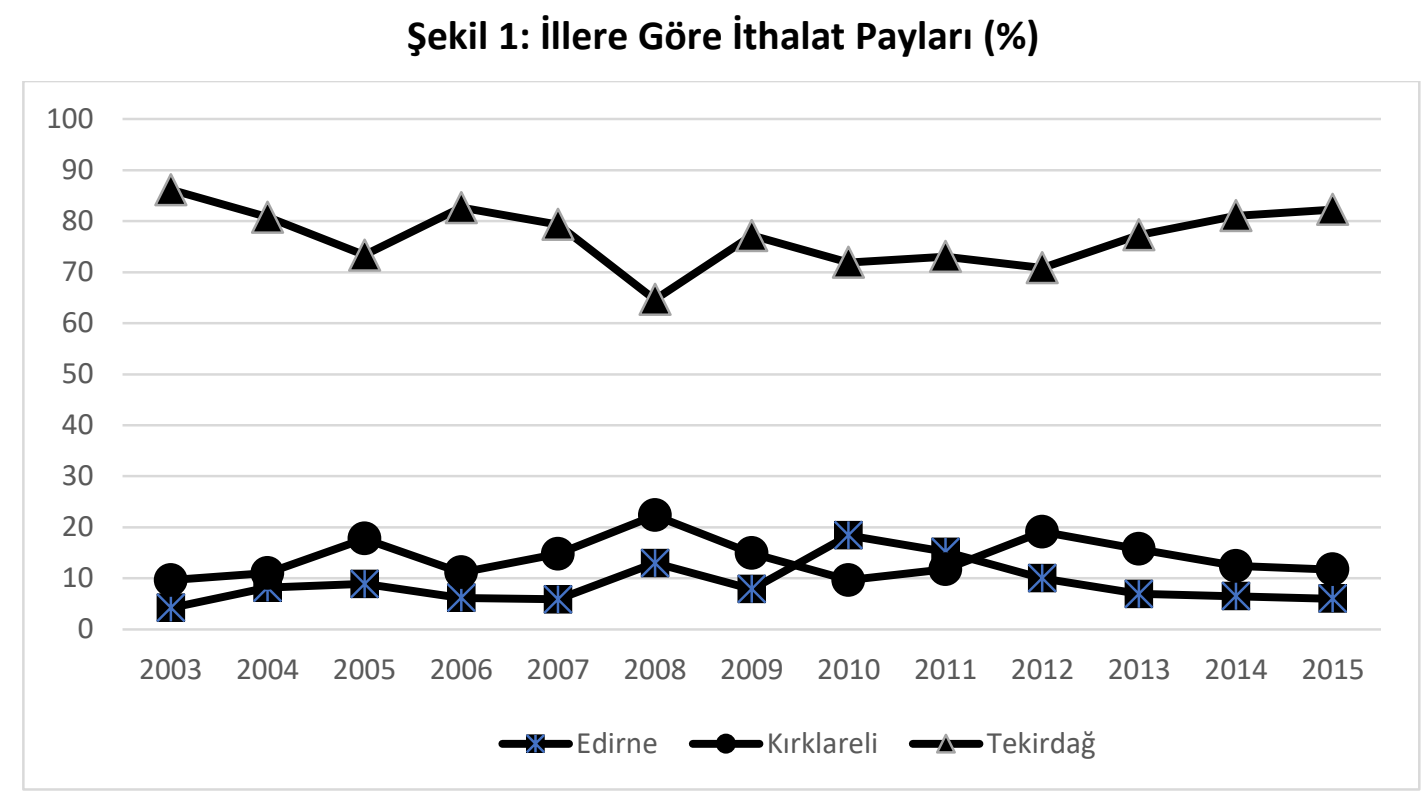

Kaynak: TÜiK Dış Ticaret mikro verileri, yazarların kendi hesaplamaları

Bunun yanında, incelemelerimiz, Trakya bölgesinin ithalat talebinin yarısından fazlasının Avrupa ülkeleri, özellikle Almanya, İtalya, İngiltere ve Fransa tarafından karşılandığını göstermektedir. Şekil 2, bölge ithalatını karşılayan beş ana kaynak ülkenin toplam ithalatı karşılama payının yıllar içerisindeki değişimini göstermektedir. Buna göre bölge ithalatının karşılanmasında 2010 yılına kadar lider durumda olan Almanya, bu yıldan sonra yerini Çin'e bırakmıştır. Şekilde raporlanan son 15 yıl içerisinde Almanya, İtalya, ABD ve İngiltere'den gerçekleştirilen ithalat sürekli olarak azalmış, bununla birlikte Çin ürünlerinin ithalatı kademeli olarak artmış ve 2003 yılında 5. Sırada bulunan Çin'i 2010 yılında bölgenin en önemli ithal malı sağlayıcısı konumuna yükselmiştir. 
Şekil 2: İthalatın Kaynağı Olan Ülkeler (2003-2015)

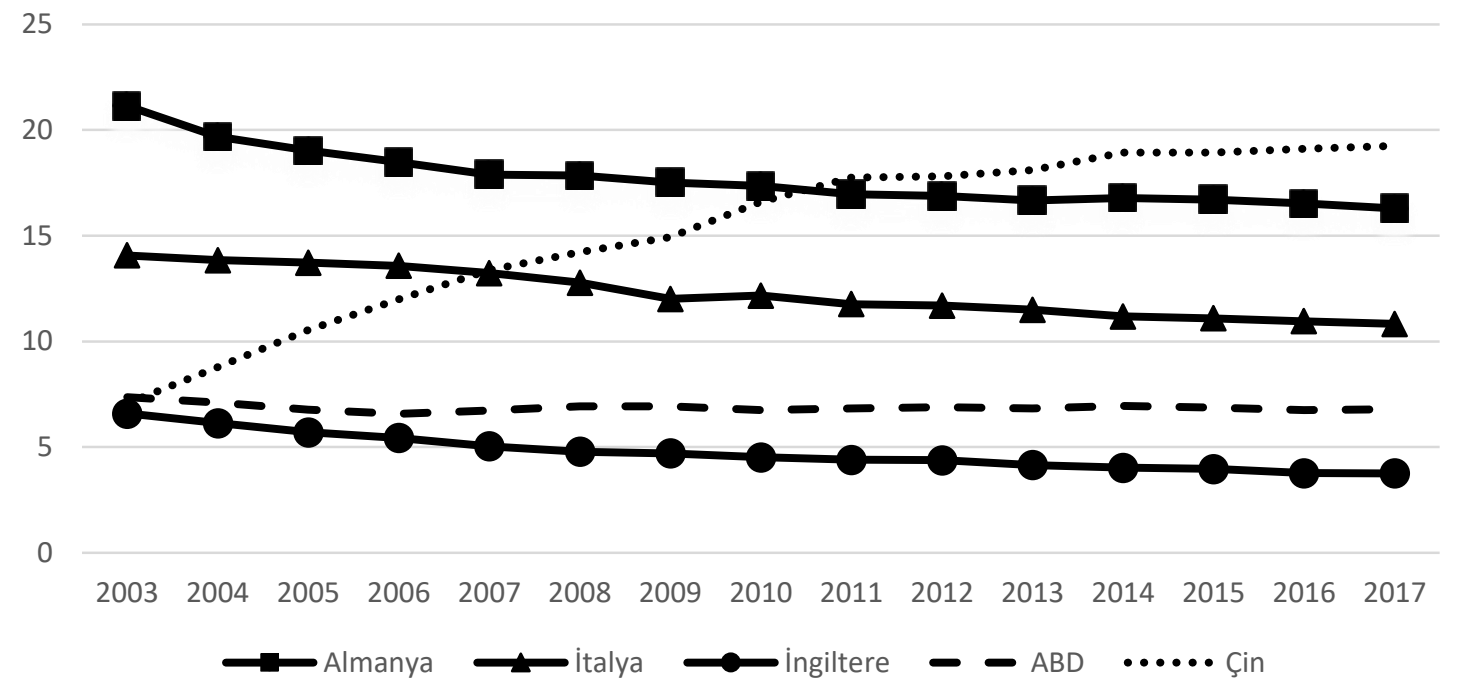

Kaynak: TÜik Dış Ticaret mikro verileri, yazarların kendi hesaplamaları

Şu aşamaya kadar sunduğumuz bilgiler bölgenin ithalat yapısı hakkında genel bir fikir vermekle birlikte, ithalata konu olan endüstriler hakkında bir bilgi sağlamamaktadır. Şekil 3, 2003-15 yılları arasında bölgenin ithalat talebini oluşturan firmaların hangi endüstrilerde faaliyet gösterdiklerini resmetmektedir. Buna göre, gözlemlenen 13 yılın ortalamasına bakıldığında, toplam ithalat içinde \%15,3 paya sahip olan firmalar "Tekstil ürünlerinin imalatı" endüstrisinde, \%15,1 paya sahip firmalar "Gıda ürünlerinin imalatı" alt sektöründe, \%13,4 paya sahip firmalar "Elektrikli teçhizat imalatı" sektöründe ve son olarak \%9,2 paya sahip firmalar "Diğer imalatlar" endüstrisinde faaliyet göstermektedirler.

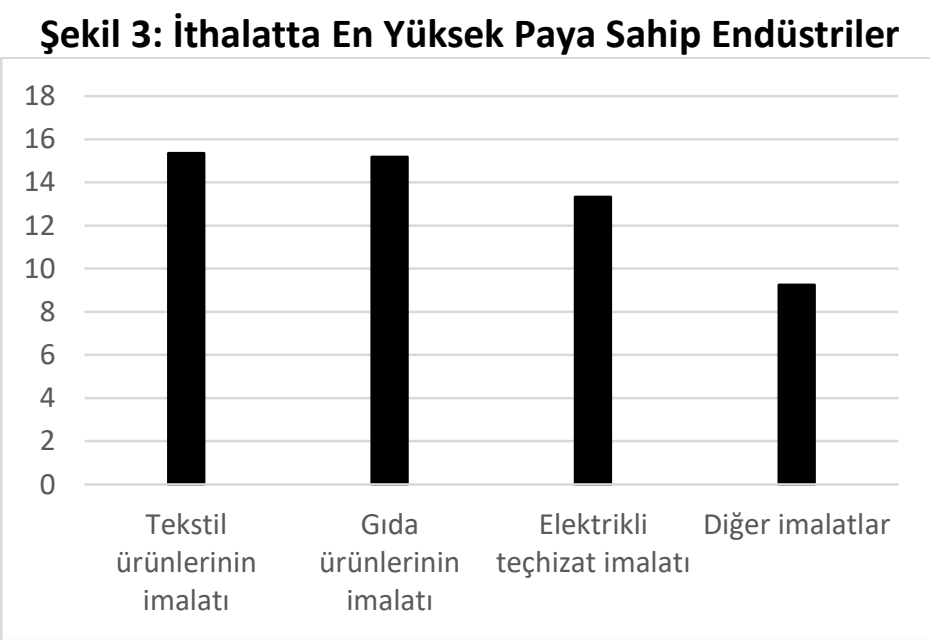

Kaynak: TÜiK Dış Ticaret mikro verileri

TÜiK tarafından sağlanan Dış Ticaret Verileri, dış ticaret faaliyetinde bulunan firmaların ihracata ve ithalata konu olan ürün bazında bilgilerini sağlayan çok kapsamlı bir mikro veri kaynağıdır. Firmaların ithal ettiği ürünler BEC kriterlerine göre üç ana kategoride gruplanmıştır: sermaye malı, ara mal ve tüketim malı. ${ }^{2}$ Buna göre, Şekil 4'te resmedilen ve Trakya bölgesinin toplam ithalatında en fazla paya sahip olan 22 kodlu "işlenmiş endüstriyel malzeme" ve 42 kodlu "Sermaye malı parça ve aksesuarları" ara mal

\footnotetext{
${ }^{2}$ Detaylı bilgi için Dip Not 2'ye bakınız.
} 
grubunda yer alırken, 41 kodlu "Sermaye malı (taşıma araç-gereci hariç)" sermaye malı kategorisinde ve son olarak 62 kodlu "Yarı dayanıklı tüketim malı" ise tüketim malı kategorisinde yer almaktadır.

\section{Şekil 4: BEC Kriterlerine Göre İthal Ürün Oranları}

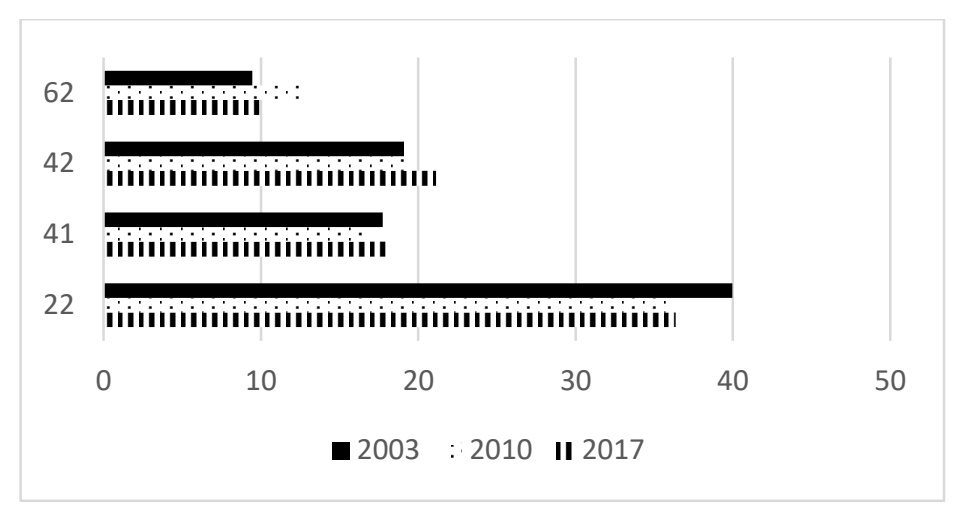

Kaynak: TÜik Dış Ticaret mikro verileri, yazarların kendi hesaplamaları Açıklama: 22 İşlenmiş endüstriyel malzeme (ara mal), 42 Sermaye malı parça ve aksesuarları (ara mal), 41 Sermaye malı (taşıma araç-gereci hariç) (sermaye malı), 62 Yarı dayanıklı tüketim malı (tüketim malı)

Adı geçen bu ürün kategorilerinin bölge ithalatındaki payının yıllar içindeki değişimini gösterebilmek için sırasıyla 2003, 2010 ve 2017'deki payları raporlanmıştır. Buna göre, ara mal kategorisinde bulunan 22 kodlu "Işlenmiş endüstriyel malzeme" ve 42 kodlu "Sermaye malı parça ve aksesuarları" alt endüstrilerinin 2017 itibari ile toplamda yaklaşık \%60'lık bir paya sahip olduğu tespit edilmiştir.

\section{2 İthal bağımlılığı}

Çalışmamızın bu bölümünde, Trakya bölgesinde faaliyet gösteren firmaların ithal bağımlılıkları hesaplanacak ve bu rakamlar sektörel bazda analiz edilecektir. Bu çalışmada, Amiti, Itskhoki ve Konings (2014)'deki gibi, firmanın ithal bağımlılığı (IB) aşağıdaki şekilde hesaplanmıştır:

$\dot{\mathrm{I}} B_{i t}=\frac{\text { Toplam ithal aramal değeri }}{\text { it }}$

Eşitlik (1)'de yer alan İB ithal bağımlıı̆̆ını temsil ederken, $i$ ve $t$ alt indisleri, sırasıyla firma ve zamanı temsil etmektedir. İthal bağımlılı̆̆ı, her bir firmanın ilgili yıl içinde ithal ettiği ara malın toplam değerinin, o firmanın toplam satışlarına bölünmesi yoluyla hesaplanmıştır.

Şekil 5’e göre, 2000'li yılların başlarında, Trakya bölgesinde faaliyet gösteren firmaların ithal bağımlılık oranları Türkiye ortalamasının çok üstünde olup \%27 seviyesindedir. Bölgedeki firmaların ithal bağımlılığı, gözlemlenen 13 yılda düşüş trendinde olup 2003 yılı için hesaplanan \%27,6 ithal bağımlılığı, 2015 yılında \%16'ya gerilemiştir. 2015 yılı için hesapladığımız rakamlar, Akat (2019)'un Türk İmalat Sanayiinde 2016 yılı için ortaya koyduğu \%16,4'lük ithal bağımlıık oranına çok yakın çıkmıştır, ancak Grafik 5 'in gösterdiği azalış trendi Özcan-Tok ve Sevinç'in (2019) ortaya koyduğu ve Türk İmalat Sanayiinde ithal bağımlılığının 2002 yılında \%16,1 iken 2012 yılında \%19,3’a çıkışını gösterdikleri bulgular ile örtüşmemektedir. Yani, 2000'lerin başından 2016'ya kadar Türk İmalat Sanayiinde ithal bağımlılığı yükselirken, bu oran Trakya bölgesinde üretim yapan firmalar için düşüştedir. 
Şekil 5: Trakya Bölgesi Üretim Sektöründe İthal Bağımlılığı

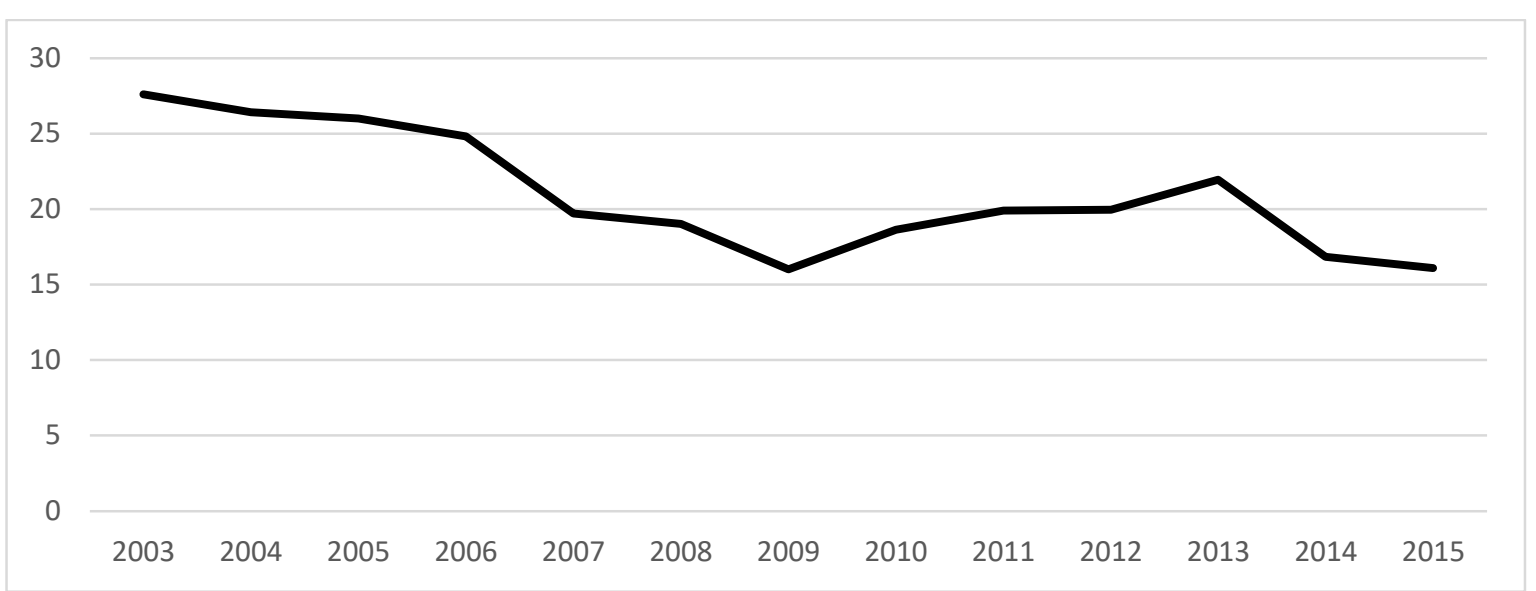

Kaynak: TÜiK Dış Ticaret ve YSH mikro verileri, yazarların kendi hesaplamaları

Bu bulgunun temel nedeni Tablo 2 incelendiğinde ortaya çıkmaktadır. Trakya Kalkınma Ajansı'na (2009) göre bölgede en önemli alt sektörler olan ve aynı zamanda Şekil 3'te belirttiğimiz gibi bölgedeki ithalat talebinin önemli bir kısmını oluşturan 13 kodlu "Tekstil ürünlerinin imalatı", 27 kodlu "Elektrikli teçhizat imalatı" ve 14 kodlu "Giyim eşyalarının imalatı" alt sektörlerindeki ithal bağımlılı̆ı ciddi oranda düşüş göstermiş, yani bu alt sektörlerdeki üretim süreçlerinde kullanılan yerli girdi miktarı artmıştır. Bununla birlikte, Tablo 2'ye göre diğer kimi alt endüstrilerde de ithal bağımlılığında gerileme yaşanmıştır. Örneğin 15 kodlu "Deri ve ilgili ürünlerin imalatı", 20 kodlu "Kimyasalların ve kimyasal ürünlerin imalatı" ve 22 kodlu "Kauçuk ve plastik ürünlerin imalatı" alt sektörlerinde de ithal bağımlılığında bir azalma olmuş ancak bu sektörlerin bölge üretiminde önemli bir paya sahip olmaması nedeni ile Şekil 5'deki trende çok etkileri olduğu düşünülmemektedir. Öte yandan, sırasıyla 24 kodlu "Ana metal sanayii", 17 kodlu "Kağıt ve kağıt ürünlerinin imalatı" ve 11 kodlu "içeceklerin imalatı" alt sektörlerinde faaliyet gösteren firmaların ithal bağımlılığında ciddi artışlar tespit edilmiştir.

Tablo 2: Seçili Sektörlerdeki İthal Bağımlılığı (\%)

\begin{tabular}{|c|c|c|c|c|c|c|c|c|c|c|c|}
\hline & $\mathbf{1 0}$ & $\mathbf{1 1}$ & $\mathbf{1 3}$ & $\mathbf{1 4}$ & $\mathbf{1 5}$ & $\mathbf{1 7}$ & $\mathbf{2 0}$ & $\mathbf{2 2}$ & $\mathbf{2 4}$ & $\mathbf{2 7}$ & $\mathbf{3 2}$ \\
\hline $\mathbf{2 0 0 3}$ & 7,6 & 11,0 & 29,7 & 24,7 & 42,1 & 9,7 & 59,2 & 29,4 & 9,6 & 34,9 & 51,0 \\
\hline $\mathbf{2 0 0 4}$ & 8,3 & 11,8 & 24,6 & 12,7 & 52,3 & 8,6 & 43,7 & 40,1 & 5,5 & 38,6 & 45,3 \\
\hline $\mathbf{2 0 0 5}$ & 17,0 & 11,0 & 17,8 & 16,1 & 19,2 & 2,8 & 52,9 & 37,1 & 26,7 & 42,6 & 45,5 \\
\hline $\mathbf{2 0 0 6}$ & 8,9 & 17,1 & 11,3 & 21,1 & 23,3 & 8,2 & 56,2 & 35,7 & 28,8 & 36,9 & 44,0 \\
\hline $\mathbf{2 0 0 7}$ & 9,2 & 15,0 & 15,7 & 20,8 & 20,5 & 8,7 & 51,0 & 30,5 & 24,1 & 38,4 & 43,0 \\
\hline $\mathbf{2 0 0 8}$ & 9,4 & 12,5 & 13,8 & 26,6 & 12,1 & 25,2 & 39,0 & 32,1 & 27,5 & 22,7 & 41,2 \\
\hline $\mathbf{2 0 0 9}$ & 9,4 & 26,1 & 9,6 & 19,7 & 16,8 & 19,7 & 40,1 & 26,9 & 23,4 & 37,9 & 41,0 \\
\hline $\mathbf{2 0 1 0}$ & 11,6 & 14,7 & 13,4 & 27,2 & 20,1 & 22,0 & 31,7 & 20,8 & 18,1 & 41,2 & 53,9 \\
\hline $\mathbf{2 0 1 1}$ & 13,2 & 27,4 & 23,4 & 14,6 & 37,0 & 24,3 & 31,9 & 18,5 & 12,9 & 37,2 & 54,4 \\
\hline $\mathbf{2 0 1 2}$ & 13,2 & 38,0 & 17,9 & 9,0 & 38,0 & 24,0 & 38,6 & 18,5 & 5,4 & 33,0 & 49,5 \\
\hline $\mathbf{2 0 1 3}$ & 9,8 & 45,8 & 22,5 & 20,7 & 27,3 & 20,5 & 26,6 & 14,2 & 25,7 & 30,3 & 46,7 \\
\hline $\mathbf{2 0 1 4}$ & 13,6 & 32,4 & 14,1 & 19,8 & 18,0 & 30,1 & 30,4 & 19,7 & 31,2 & 30,6 & 56,2 \\
\hline $\mathbf{2 0 1 5}$ & 8,5 & 29,4 & 15,0 & 17,1 & 13,8 & 24,8 & 30,4 & 19,1 & 32,1 & 28,2 & 47,6 \\
\hline
\end{tabular}

Kaynak: TÜiK Dış Ticaret ve YSH mikro verileri, yazarların kendi hesaplamaları

Açıklama: 10 Gıda ürünlerinin imalatı, 11 İçeceklerin imalatı, 13 Tekstil imalatı, 14 Giyim eşya imalatı,

15 Deri ve ilgili ürünlerin imalatı, 17 Kağıt ve kağıt ürünlerinin imalatı, 20 Kimyasalların ve kimyasal ürünlerin imalatı, 22 Kauçuk ve plastik ürünlerin imalatı, 24 Ana metal sanayii, 27 Elektrikli teçhizat imalatı 
Daha önce belirttiğimiz gibi, artan ithal bağımlıı̆̆ı dış açığın kronik bir hal almasına yol açan bir problemdir. Bu noktada, toplam ihracat içinde önemli yer tutan sektörlerde yerli ara malı kullanım oranı, dış açığın seyrini belirleyen önemli bir göstergedir. Eğer ihracatçı endüstrilerde yerli üretim ara malı kullanımı artarsa, bu durum dış açık üzerinde gerileyici etki yaratacakken, aksi durum, yani bu sektörlerde ithal ara malı kullanımında bir artış dış açığı arttıracaktır. TÜik Dış Ticaret verilerine göre, 2015 yılı itibari ile Trakya bölgesindeki en ihracatçı sektörler sırası ile 10 kodlu "Gıda ürünlerinin imalatı", 13 kodlu "Tekstil ürünlerinin imalatı", 14 kodlu "Giyim eşyalarının imalatı", 20 kodlu "Kimyasalların ve kimyasal ürünlerin imalatı" ve 22 kodlu "Kauçuk ve plastik ürünlerin imalatı" olarak hesaplanmıştır. Şekil 6’ya göre, 2003-15 yılları arasında adı geçen bu beş ihracatçı alt sektörde de ithal bağımlılığında bir gerileme söz konusudur. Buna göre bölge ekonomisinin, 2003-15 yılları arasında gözlemlenen dış açık artışında, ithal bağımlılığı üzerinden, bir payı olmadığı gözlemlenmektedir.

\section{Şekil 6: En Yüksek İhracat Oranına Sahip 5 Alt Endüstrideki İthal Bağımlılığı}

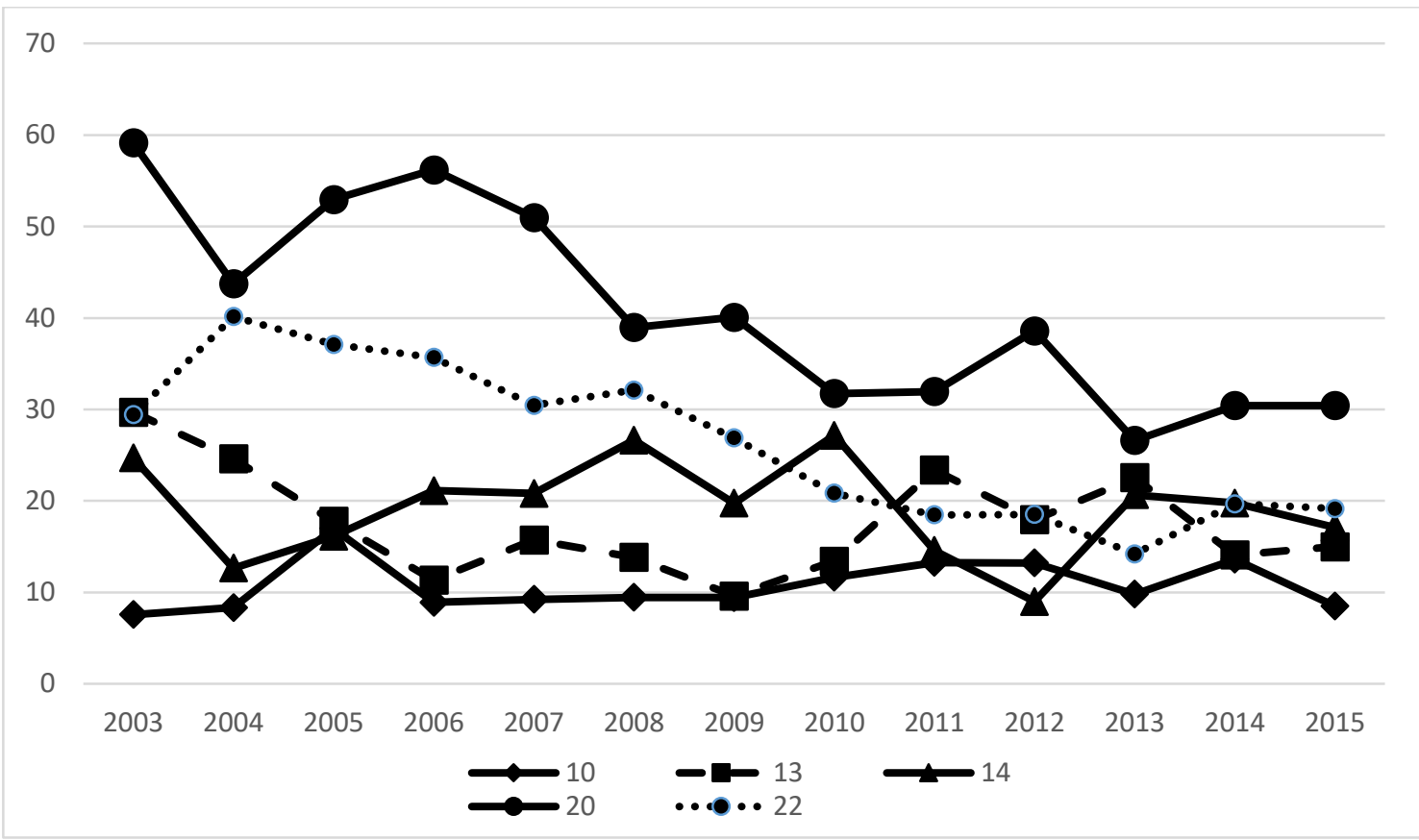

Kaynak: TÜiK Dış Ticaret ve YSH mikro verileri, yazarların kendi hesaplamaları Açıklama: 10 Gıda ürünlerinin imalatı, 13 Tekstil imalatı,14 Giyim eşyalarının imalatı, 20 Kimyasalların ve Kimyasal ürünlerin imalatı, 22 Kauçuk ve plastik ürünlerin imalatı

\section{Sonuç}

Bu makalede, 2003-2017 yılları arasında Trakya bölgesinde üretim sektöründe faaliyet gösteren firmaların ithalat yapısı ve ithal ara mal kullanım yoğunlukları analiz edilmiştir. Çalışmamız bu yönüyle bir ilk niteliği taşımakta olup, bulgularımız bölge ekonomisinin daha önce raporlanmamış özelliklerini ortaya koymaktadır. Buna göre, bölgede gerçekleştirilen ithalatın çok büyük bir kısmının Tekirdağ'da üretim yapan firmalar tarafından yapıldığı ortaya konmuştur. Buna ek olarak, en önemli ithal malı sağlayıcı ülkelerin 2000'lerin başında Almanya ve İtalya iken, bu ülkelerin zamanla paylarını Çin'e kaptırdıkları tespit edilmiştir.

Çalışmamızda, Türkiye ekonomisinin en önemli sorunlarından birisi olan ithal bağımlılığı incelenmiş ve Trakya bölgesinin toplam ithalatında en fazla paya ara mal ithalatının damga vurduğu gösterilmiştir. Buna göre, bölgede faaliyet gösteren firmaların ithal bağımlılık oranları 2003 yılı için \%27,6 iken, 2015 yılında \%16'ya gerilemiştir. Bu gerilemenin en önemli sebeplerinden birisi olarak, yıllar içinde bölgede ithalat gerçekleştiren firma sayısındaki düşüş karşımıza çıkmaktadır. Bu düşüşün iki temel nedeni 
öne çıkmaktadır. Bunlardan birincisi ulusal paranın değer kaybetmesi sonucunda ithalatın daha maliyetli hale gelmesi olabilir. Bir diğer potansiyel açıklama da üretim sürecinde kullanılan ithal ara malının ikamesinin yurt içinden temin edilmesidir.

Yıllar içerisinde bölgede üretim sektöründe faaliyet gösteren firma sayısı ve ithalat hacmi artmış olmasına rağmen ithal bağımlılığında düşüş gözlenmesinin bir diğer nedeni, bölgedeki ithalat talebinin önemli bir kısmını oluşturan "Tekstil ürünlerinin imalatı", "Elektrikli teçhizat imalatı" ve "Giyim eşyalarının imalatı" gibi alt sektörlerde gözlenen ithal bağımlılığı oranındaki azalış olarak tespit edilmiştir. Bu alt sektörlerdeki bahsi geçen gelişmelerin nedenlerini ortaya koymak bundan sonraki çalışmalarımızın konusu olacaktır.

\footnotetext{
Hakem Değerlendirmesi: Dış, bağımsız.

Çıkar Çatışması: Yazar çıkar çatışması bildirmemiştir.

Finansal Destek: Yazar bu çalışma için finansal destek almadığın beyan etmiştir.
}

\section{Kaynakça}

Almeida, R. \& Fernandes, A.M. (2008), Openness and technological innovations in developing countries: Evidence from firm-level surveys, The Journal of Development Studies, Vol. 44 No. 5, 701-727. https://doi.org/10.1080/00220380802009217

Akat, A.S. (2019), ìnracat ithalata ne kadar bağımlı?, iktisat ve Toplum, Sayı: 101, 7-13. Erişim adresi: https://iktisatvetoplum.com/

Alkın, H. (2020), Türkiye'nin ihracatının katma değer dağııımı ve ithal girdi bağımlılığı: 2000-2014 dönemi için küresel değer zinciri analizi. Akdeniz iiBF Dergisi, 20(1), 66-89. https://doi.org/10.25294/auiibfd.734201

Amiti, M. \& Konings, J. (2011), Trade liberalization, intermediate inputs, and productivity: Evidence from Indonesia," American Economic Review, 97, 1611-1638.

Andersson, T., ve Fredriksson, T. (2000), Distinction between intermediate and finished products in intrafirm trade, International Journal of Industrial Organization, 18, 773-792. https://doi.org/10.1016/S0167-7187(98)00041-1

Aydın, F., Saygılı, H., Saygılı, M. ve Yılmaz, G. (2010). Dış ticarette küresel eğilimler ve Türkiye ekonomisi, Türkiye Cumhuriyet Merkez Bankası Çalışma Tebliği, No:10-01. Erişim adresi: https://www.tcmb.gov.tr/wps

Campa, J., ve Goldberg L.S. (1997), Evolving external orientation of manufacturing industries: Evidence from four countries, NBER Working Paper (No: 5919), National Bureau of Economic Research, Cambridge, Mass. DOI 10.3386/w5919

Demir, N. ve Kula, M. (2008), "Türkiye ekonomisinin sektörler arası bağlantılarında ihracat-ithalat ilişkileri", Uluslararası Ekonomi ve Dış Ticaret Politikaları, 3(1-2), ss. 85-116.

Dineri, E., ve Nalan, I. (2021) İthalat bağımlılığı ve Türkiye ekonomisinde imalat sanayi: Hatemi-J asimetrik nedensellik testi. Gazi iktisat ve işletme Dergisi, 7(1), 68-82.

Dutta, P.B., \& Ghosh, N. (2021), Wage inequality and unemployment in the presence of imported intermediate goods: A theoretical analysis, Foreign Trade Review. Advance online publication https://doi.org/10.1177/0015732520986893. 
Eckhardt, J. (2013). EU Unilateral Trade Policy-Making: What role for import-dependent firms?, Journal of Common Market Studies, 51(6), 989-1005. https://doi.org/10.1111/jcms.12059

Ekonomi Bakanlığı (2017), Girdi tedarik stratejisi eylem planı, Erişim adresi: https://ticaret.gov.tr/data/5b9230df13b87613646658ce/gites_raporu.pdf

Feenstra, R.C., ve Hanson G.H. (1996), Globalization, outsourcing and wage inequality. American Economic Review, 86(2), 240-245. Erişim adresi: https://www.jstor.org/

Goldberg, P.K., Khandelwal, A.K., Pavcnik, N., ve Topalova, P. (2010), Imported intermediate inputs and domestic product growth: Evidence from India, The Quarterly Journal of Economics, 125(4), 1727 - 1767. https://doi.org/10.1162/qjec.2010.125.4.1727

Özcan-Tok, E. ve Sevinç, O. (2019), Üretimin ithal girdi yoğunluğu: girdi-çıktı analizi, TCMB Ekonomi Notları (Sayı 2019-06). Erişim adresi: https://www.tcmb.gov.tr/wps/

Ersungur, Ş., Ekinci, E. ve Takım, A. (2011), Türkiye ekonomisinde ithalata bağımlılıktaki değişme: girdiçıktı yaklaşımıyla bir uygulama. Atatürk Üniversitesi iktisadi ve Idari Bilimler Dergisi, 25. Erişim adresi: https://dergipark.org.tr/tr/pub/atauniiibd/

Eşiyok, A., (2008), Türkiye ekonomisinde üretimin ve ihracatın ithalata bağımlılı̆̆ı dış ticaretin yapısı: girdiçıktı modeline dayalı bir analiz, Uluslararası Ekonomi ve Dış Ticaret Politikaları, Cilt 3(1-2), 117160.

Halpern, L., Koren, M. \& Szeidl, A. (2015), Imported inputs and productivity, American Economic Review, 105, 3660-3703. http://dx.doi.org/10.1257/aer.20150443

Hiroyuki, K. \& Rodrigue, J. (2008), Does the use of imported intermediates increase productivity? Plantlevel evidence, Journal of Development Economics, 87(1): 106-18. https://doi.org/10.1016/j.jdeveco.2007.12.008

Kleinert, J. (2004), The role of multinational enterprises in globalization (Vol. 326). Berlin, Germany: Springer Science \& Business Media.

López, R.E., \& Rodrik, D. (1990), Trade restrictions with imported intermediate inputs, Journal of Development Economics, 34(1-2), 329-338. doi:10.1016/0304-3878(90)90088-s.

Özenç, B. ve Düşündere, A. (2017), 2000 sonrasında ithal ara malı bağımlılığı ve katma değer üretimi, Türkiye Ekonomi Politikaları Araştırma Vakfı Değerlendirme Notu (No: 201713). Erişim adresi: https://www.tepav.org.tr/tr/haberler/s/4187

Roy, S. (2020). Intermediate input imports, domestic input use and firm-level outcomes: Evidence from survey data. Foreign Trade Review, 55(3), 320-336. https://doi.org/10.1177/0015732520920467

Saygılı, S., Cihan, C., Yalçın, C., ve Hamsici, T. (2010). Türkiye imalat sanayiin ithalat yapısı, TCMB Çalışma Tebliği, 10/02. Erişim adresi: https://www.tcmb.gov.tr/wps/wcm/

Türkan, E. (2006), Türkiye'de üretimin ithalat ve ihracat bağımlıı̆̆ı, Türkiye Cumhuriyet Merkez Bankası Kitaplar-Çalışmalar, Ankara

Ueda, K. (1983), Trade balance adjustment with imported intermediate goods: the Japanese case. The Review of Economics and Statistics, 65(4), 618-625.

Veeramani, C. (2009), Impact of imported intermediate and capital goods on economic growth: A cross country analysis. SSRN working paper series (WP-2008-029) DOI: 10.2139/ssrn.1325181.

Yükseler, Z. ve Türkan, E. (2008), Türkiye'nin üretim ve dış ticaret yapısında dönüşüm: Küresel yönelimler ve yansımalar, TCMB-TÜSIAD-EAF ortak yayını (No: TÜSIAD-T/2008-02/453). Erişim adresi: 
https://tusiad.org/tr/tum/item/4021-turkiyenin-uretim-ve-dis-ticaret-yapisinda-donusum-kuresel-makroekonomik-yonelimler-ve-yansimalar-raporu-ozet-bulgulari 